\title{
An outbreak of francisellosis in wild-caught Celtic Sea Atlantic cod, Gadus morhua L., juveniles reared in captivity
}

\section{N M Ruane ${ }^{1}$, M Bolton-Warberg ${ }^{2}$, H D Rodger ${ }^{3}$, D J Colquhoun ${ }^{4}$, M Geary ${ }^{1}$, S J McCleary ${ }^{1}$, K O’Halloran², K Maher², D O'Keeffe ${ }^{2}$, L Mirimin ${ }^{2}$, K Henshilwood ${ }^{1}$, F Geoghegan ${ }^{1}$ and R D Fitzgerald ${ }^{2}$}

\author{
1 Fish Health Unit, Marine Institute, Oranmore, County Galway, Ireland \\ 2 Carna Research Station, Ryan Institute, National University of Ireland, Galway, Ireland \\ 3 Vet-Aqua International, Oranmore Business Park, Oranmore, County Galway, Ireland \\ 4 Norwegian Veterinary Institute, Oslo, Norway
}

Keywords: Atlantic cod, disease, Francisella noatunensis subsp. noatunensis, wild fish.

Atlantic cod, Gadus morhua L., is among the most important commercial fishing species in the north-east Atlantic and from the late 1990s was considered one of the most promising species for future aquaculture development (Rosenlund \& Skretting 2006; Rosenlund \& Halldórsson 2007). In the last decade, production increased to over 20000 tonnes with the majority of this coming from Norway and, to a lesser extent, Canada and Iceland. However, in recent years, farming efforts have waned and the industry has not developed in line with earlier expectations (Rosenlund \& Skretting 2006). Several factors are now perceived as critical impediments to cod farming in northwestern Europe, including market trade forces, technical issues and, critically, a number of biological bottlenecks such as juvenile quality (Koedijk et al. 2010), early sexual maturation (Imsland et al. 2013) and certain disease conditions (Samuelsen et al. 2006). One of these diseases, francisellosis, has emerged as a serious issue for farmed cod production (Birkbeck, Feist \& Verner-Jeffreys
2011; Colquhoun \& Duodu 2011). Francisellosis in cod is a systemic granulomatous inflammatory disease which is often chronic in nature and is characterized by numerous white nodules clearly visible on the internal organs. The disease is caused by Francisella noatunensis subsp. noatunensis (Mikalsen et al. 2007; Ottem et al. 2009), a nonmotile, Gram-negative, aerobic, intracellular cocco-bacilli which was first reported in farmed Atlantic cod in Norway in 2004 (Nylund et al. 2006; Olsen et al. 2006).

As part of a nationally funded project (EIRCOD), eggs of different family groups (full and half-sibs) have been collected annually since 2008, from wild-caught cod broodstock in the Celtic Sea. In March 2009, 608 juvenile cod $(\sim 100 \mathrm{~g})$ were collected via trawl capture from a nursery area in the Waterford Estuary on the south coast of Ireland (grid reference: Lat $52^{\circ} 14^{\prime} 52 \mathrm{~N}$; Long $\left.6^{\circ} 59^{\prime} 26 \mathrm{~W}\right)$. A large sample $(n=259)$ of the catch was immediately culled and stored-frozen for later examination (150 of these fish subsequently tested negative for Francisella sp. by real-time PCR). The remaining fish $(n=349)$ were then transferred overland $(300 \mathrm{~km}$ in $5 \mathrm{~h})$ in aerated tanks to Carna Research Station (NUIG), Co. Galway. At the station, the biomass was distributed evenly among three glass reinforced plastic (GRP) tanks ( $2 \mathrm{~m}$ diameter, $0.8 \mathrm{~m}$ depth) each with $1700 \mathrm{~L}$ 
capacity. Water was supplied to holding tanks via a flow-through ambient system, with both intake and effluent being filtered and UV-sterilized. Temperature was measured and recorded using deployed Tiny Tags $^{\circledR}{ }^{\circledR}$ with means ranging from $8{ }^{\circ} \mathrm{C}$ in March to $18{ }^{\circ} \mathrm{C}$ in July. Oxygen concentration was monitored twice daily in the outlet of each tank and maintained at $>80 \%$ saturation. Dark polythene covers were placed over tanks to minimize disturbance to fish during this initial acclimation phase. In addition to the wild-caught juveniles being held at this time, cod from 2 yearclasses $\left(2008 \mathrm{1+}^{+}\right.$and 2009 0+) were also held in the same facility. These fish had been collected as eggs from wild broodstock during Marine Institute surveys in the Celtic Sea.

Initial mortality occurred following capture and transfer to holding tanks and during early acclimation, but this abated after the first 2 weeks, and the number remaining by May 21 was 302 ( $86.8 \%$ survival). On that first sampling, it was apparent that the overall mean weight of fish had not increased appreciably since capture (from $\sim 100$ to $123 \mathrm{~g}$ ), and there was a considerable size disparity in the stocks. Hence, they were sorted into three arbitrary size grades: small $(n=120$; mean $71.7 \mathrm{~g})$, medium $(n=134$; mean $131.1 \mathrm{~g})$ and large $(n=48$; mean $249.1 \mathrm{~g})$. Mortalities continued to occur in all three size grades over the remaining weeks (Fig. 1). Overall, 50\% mortality was recorded from initial stocking until the final cull with significantly greater mortalities in the small grade $\left(\chi^{2}=9.75 ; \mathrm{df}=2 ; P \leq 0.01\right)$.

On 18 August 2009, 18 of the wild-caught juvenile stock were sampled as part of a surveillance inspection under EU Directive 2006/ 88/EC. Aeromonas salmonicida was isolated from a gill swab on Colombia blood agar supplemented with $2 \%$ salt $(\mathrm{CBA}+)$, and a Vibrio sp. and Pseudomonas sp. were isolated on $\mathrm{CBA}+$, seawater agar (SWA) and cysteine heart agar (CHA) plates from kidney swabs. All agar plates were produced commercially (Fannin Ltd), and the bacteria were identified by standard primary (including vibriostatic disc 0129 (Oxoid)) and secondary biochemical tests (API 20E, API NE, API ZYM; Biomerieux). No virus was isolated from three separate pools of tissues (heart, kidney and spleen) tested using BF-2 and EPC cell lines. The presence of significant clinical pathologies consistent with francisellosis, such as extensive granulomatous, white nodules on the surface of the major internal organs, was evident in a large proportion $(\sim 61 \%)$ of the sampled fish (Fig. 2a,b). During the final cull, it was observed that, in severe cases, these granulomas presented as enlarged ascites on the surface of the spleen (Fig. 2b). Three fish were examined by histopathology, and after initial haematoxylin and eosin staining, there was evidence of a systemic bacterial infection causing necrotic-centred granulomas in the internal organs of each fish (Fig. 2c). Further staining showed the presence of intracellular bacteria that were ZiehlNielsen negative and Giemsa positive. Francisella noatunensis-specific immunohistochemistry, as described by Zerihun et al. (2011), was performed on paraffin-embedded sections resulting in abundant positive staining of bacterial cells within the granulomatous tissues (Fig. 2d). The three tissue homogenates used for virological testing were also

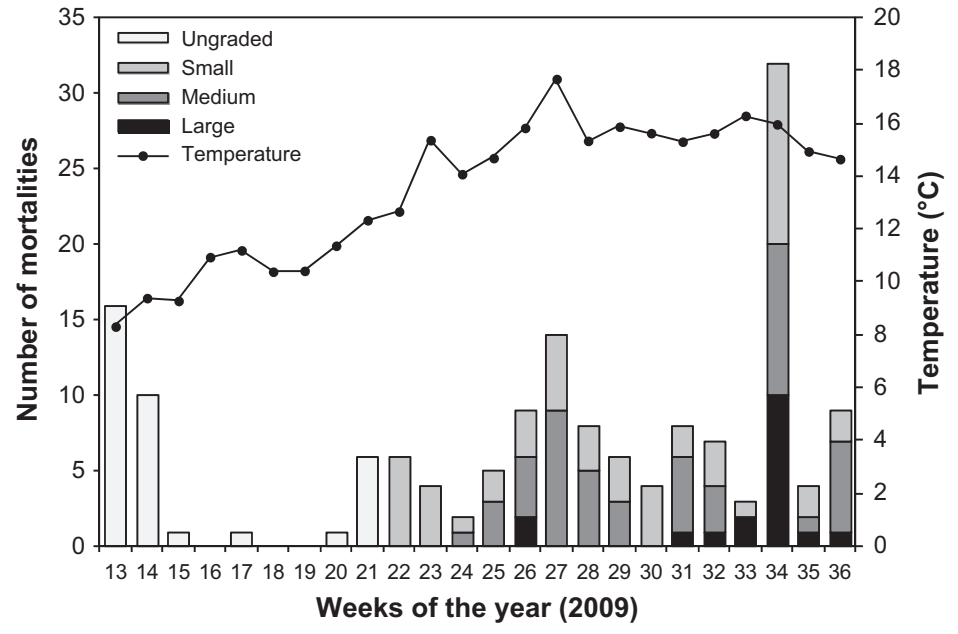

Figure 1 Weekly mortalities in wildcaught Atlantic cod juveniles and mean water temperature in 2009 at Carna Research Station. Juveniles were graded into three size groups in week 21 and final culling took place in week 37 . 

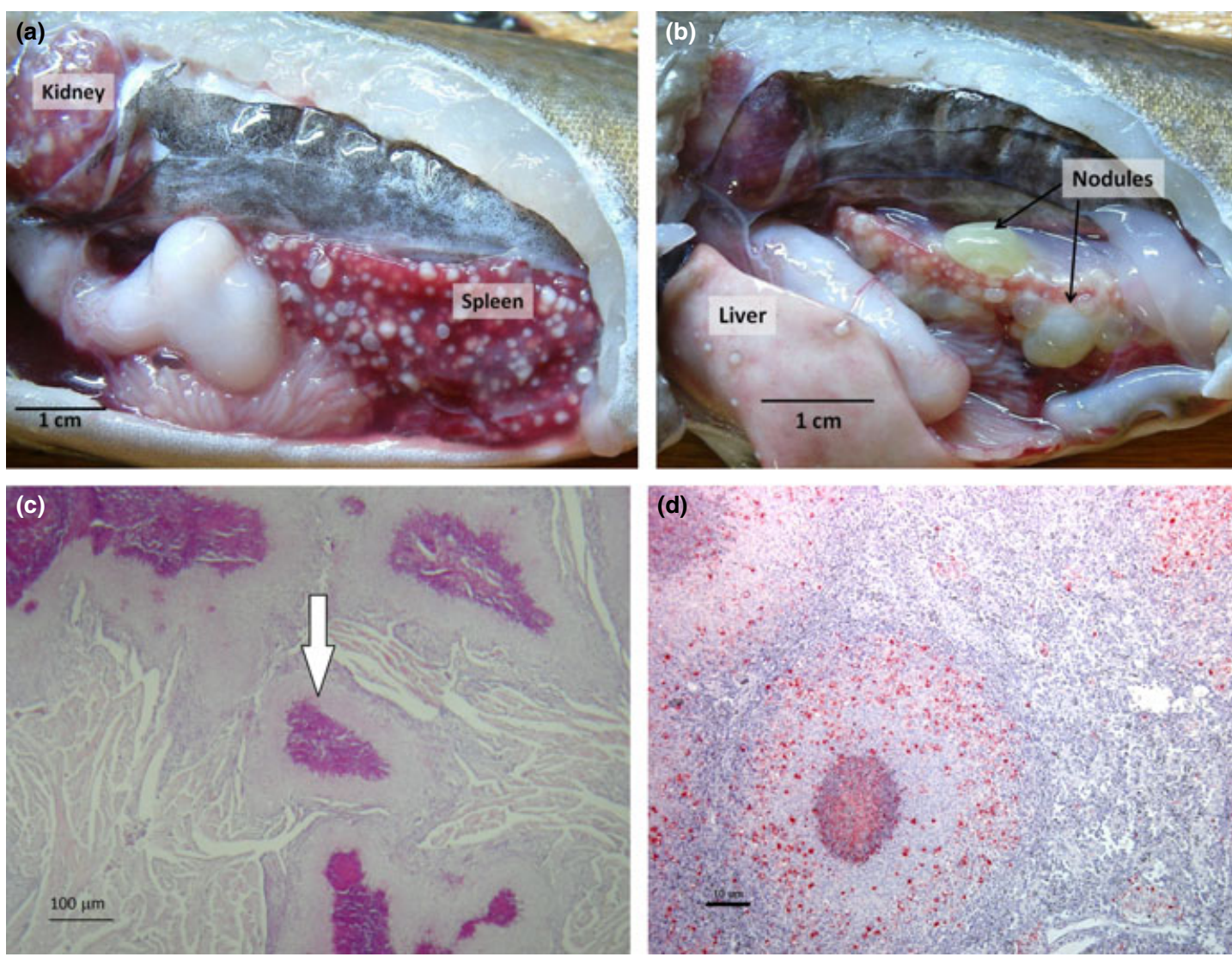

Figure 2 Gross clinical appearance on autopsy (a,b) showing characteristic multiple granulomas (white nodules) typical of francisellosis on the surface of the kidney, spleen and liver from infected Atlantic cod. In some cases, enlarged, fluid-filled nodules were evident on the spleen (b). Heart tissue stained by haematoxylin and eosin showing multiple necrotic-centred granulomas (c) and immunostaining (dark dots) with Francisella-specific antibody around granulomas in the spleen (d).

used to screen for Francisella sp. by real-time RT-PCR using a specific primer set and probe amplifying a region of the outer membrane protein FopA (Ottem et al. 2008). Total RNA was extracted using the RNeasy Mini Kit (Qiagen), and a one-step real-time RT-PCR was then carried out using the Platinum ${ }^{\circledR}$ Quantitative RT-PCR Thermoscript $^{\mathrm{TM}}$ system (Applied Biosystems). The reaction was performed on the ABI 7500 real-time PCR system (Applied Biosystems), and all three tissue homogenate pools tested positive. Cod elongation factor $1 \alpha$ (ELF-1 $\alpha$ ) was used as an internal process control (Olsvik et al. 2006), and F. noatunensis subsp. noatunensis NCIMB $14265^{\mathrm{T}}$, isolated from Norwegian cod, was used as a positive control.

Follow-up sampling took place on 10 and 11 September 2009 with the aim of isolating Francisella noatunensis from the infected wild-caught fish and also to screen the other year-classes within the facility. Therefore, kidney swabs taken from five infected wild-caught fish were plated onto CHA plates supplemented with $10 \%$ vancomycin and incubated at $22{ }^{\circ} \mathrm{C}$ as standard. This resulted in the growth of pure off-white, smooth convex colonies on all inoculated plates. The bacteria were found to be Gram-negative cocci, non-motile, oxidase and catalase positive and only grew on CHA plates with the best growth observed at $22{ }^{\circ} \mathrm{C}$, based on counting bacterial colonies. No reaction with the standard secondary biochemical tests occurred; however, the API ZYM test kit indicated that the isolate was esterase, esterase lipase, acid phosphatase and naphtol-AS-biphosphohydrolase positive.

To confirm the identity of the bacterium, a partial sequencing of the 16S ribosomal RNA gene using universal eubacteria primers (Lane et al. 


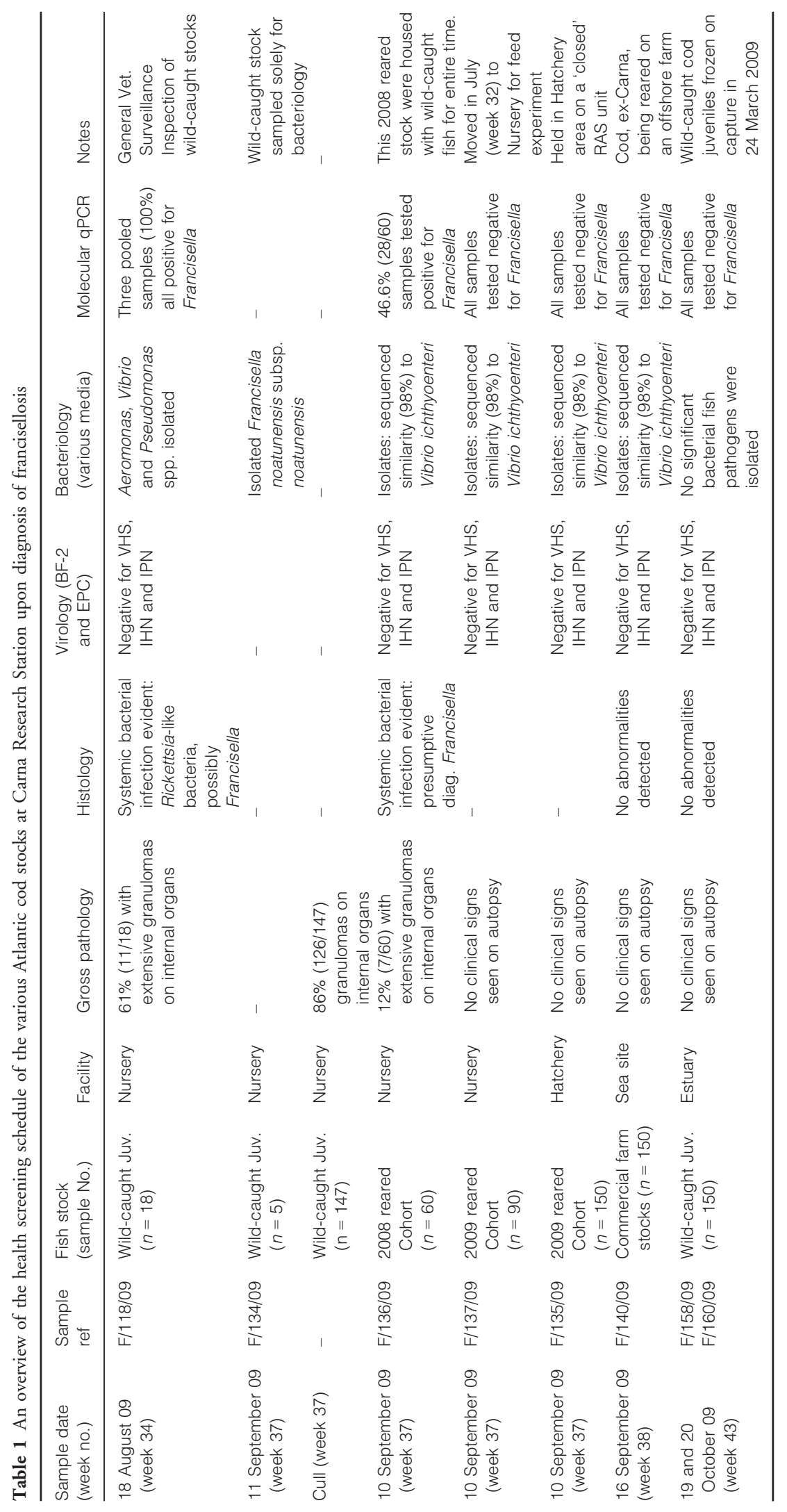


1985; Weisburg et al. 1991): 8F (5'-AGAGTTTG ATCCTGGCTCAG-3') and 536R (5'-GWATTA CCGCGGCKGCTG-3') was performed on three isolates. Partial sequences were also obtained from the following housekeeping genes: groEL (889 bp), shdA (486 bp), rpoB (494 bp) and pgm (655 bp) using primers described by Mikalsen et al. (2007) and putA (491 bp) using primers described by Ottem et al. (2009). BLAST analysis revealed 100\% sequence identity with Francisella noatunensis subsp. noatunensis isolated from farmed Atlantic cod in Norway for all sequenced loci.

The two other Atlantic cod year-classes held at Carna (2008 1+ and 2009 0+) were sampled for virology, bacteriology, histopathology and molecular screening by real-time RT-PCR as described above. No virus was isolated from any of the samples, and a Vibrio sp. was isolated from a number of fish from both year-classes (sequencing of the partial 16S rRNA gene as described above showed that the bacteria had $98 \%$ similarity to Vibrio ichthyoenteri). Seven of the 602008 year-class fish sampled had visible signs of disease (granulomas), and histopathological examination indicated a systemic bacterial infection. There were no signs of disease in the 2009 year-class fish. Kidney tissues taken for molecular analysis during this testing showed 0/90 2009 year-class and 28/60 2008 year-class tested positive for Francisella sp. Due to the occurrence of granulomas and positive molecular results in the $20081+$ year-class Atlantic cod, it was decided to cull both year-classes for quarantine purposes. When culled, it was found that $\sim 7 \%$ of the $20081+$ fish $(n=337$; mean $413.2 \mathrm{~g})$ and $0 \%$ of the $20090+$ fish $(n=440$; mean $6.1 \mathrm{~g}$ ) showed visible signs (white nodules) of the disease. It is noteworthy that the older year-class had been present in the nursery building for the entire duration of the acclimation process with the wild-caught fish, while the younger fish had only been transferred into that area in July 2009. When the wild-caught fish were culled, visible signs of disease were noted in $85 \%$ of those fish. Other Atlantic cod groups from the research facility were also tested for Francisella, and all details are shown in Table 1.

The use of wild Atlantic cod as broodstock for supplementing the production of juveniles is a common practice (Rosenlund \& Halldórsson 2007). A major disadvantage of this can be the accidental introduction of pathogens. Although initial samples culled at capture were negative, in this case it is likely that the cause of the infection was the wild fish themselves. An alternative explanation is that the intake water was the source of infection. However, this water was filtered and UV-irradiated before entering the system, and given the fact that there have not been any further outbreaks since 2009, suggests that this is unlikely. Characterization of the causative agent (Mikalsen et al. 2007; Ottem et al. 2007) and development of sensitive diagnostic methods, both molecular based and culture, have led to a greater awareness of francisellosis and its occurrence in farmed and wild fish (Colquhoun \& Duodu 2011). There is also evidence that the bacterium is prevalent in wild Atlantic cod along the west coasts of Sweden and Norway (Ottem et al. 2008; Colquhoun \& Duodu 2011). In the 1980s, there were reports of a visceral granulomatous disease in cod from the North Sea of unknown aetiology. A study using archived formalin-fixed paraffin-embedded tissue blocks of Atlantic cod sampled from the southern North Sea in 1988 showed that $F$. noatunensis was the causative agent of this disease (Zerihun et al. 2011). The present study provides, by extending its recognized distribution range into the Celtic Sea, further evidence that $F$. noatunensis subp. noatunensis is widespread in the north-east Atlantic. It is clear that this bacterium will, unless a vaccine is developed, continue to threaten the future development Atlantic cod farming in a number of northern European countries.

\section{Acknowledgements}

The authors would like to acknowledge the financial support of the EIRCOD project, funded under the Sea Change initiative with the support of the Marine Institute and the Marine Research Sub-programme of the National Development Plan 2007 2013 and co-funded by the European Regional Development Fund. The authors generously acknowledge the assistance of all staff at Carna Research Station and those of the Fish Health Unit, Marine Institute. Dr. Adam Zerihun, Norwegian Veterinary Institute, is also acknowledged for his assistance with the immunohistochemistry.

\section{References}

Birkbeck T.H., Feist S.W. \& Verner-Jeffreys D.W. (2011) Francisella infections in fish and shellfish. Journal of Fish Diseases 34, 173-187. 
Colquhoun D.J. \& Duodu S. (2011) Francisella infections in farmed and wild aquatic organisms. Veterinary Research 42, 47.

Imsland A.K., Hanssen H., Foss A., Vikingstad E., Roth B., Bjørnevik M., Powell M., Solberg C. \& Norberg B. (2013) Short-term exposure to continuous light delays sexual maturation and increases growth of Atlantic cod in sea pens. Aquaculture Research 44, 1665-1676.

Koedijk R.M., Folkvord A., Foss A., Pittman K., Stefansson S.O., Handeland S. \& Imsland A.K. (2010) The influence of first-feeding diet on the Atlantic cod Gadus morhua phenotype: survival, development and longterm consequences for growth. Journal of Fish Biology 77 , $1-19$.

Lane D.J., Pace B., Olsen G.J., Stahl D.A., Sogin M.L. \& Pace N.R. (1985) Rapid determination of 16 S ribosomal RNA sequences for phylogenetic analyses. Proceedings of the National Academy of Sciences USA 82, 6955-6959.

Mikalsen J., Olsen A.B., Tengs T. \& Colquhoun D.J. (2007) Francisella philomiragia subsp. noatunensis subsp. nov., isolated from farmed Atlantic cod (Gadus morhua L.). International Journal of Systematics and Evolutionary Microbiology 57, 1960-1965.

Nylund A., Ottem K.F., Watanabe K., Karlsbakk E. \& Krossøy B. (2006) Francisella sp. (Family Francisellaceae) causing mortality in Norwegian cod (Gadus morhua) farming. Archives of Microbiology 185, 383-392.

Olsen A.B., Mikalsen J., Rode M., Alfjorden A., Hoel E., Straum-Lie K., Haldorsen R. \& Colquhoun D.J. (2006) A novel systemic granulomatous inflammatory disease in farmed Atlantic cod, Gadus morhua L., associated with a bacterium belonging to the genus Francisella. Journal of Fish Diseases 29, 307-311.

Olsvik P.A., Kristensen T., Waagbø R., Tollefsen K.E., Rosseland B.O. \& Toften H. (2006) Effects of hypo- and hyperoxia on transcription levels of five stress genes and the glutathione system in liver of Atlantic cod Gadus morhua. Journal of Experimental Biology 209, 2893-2901.
Ottem K.F., Nylund A., Karlsbakk E., Friis-Møller A.F. \& Krossøy B. (2007) Characterization of Francisella sp., GM2212, the first Francisella isolate from marine fish, Atlantic cod (Gadus morhua). Archives of Microbiology 187, 343-350.

Ottem K.F., Nylund A., Isaksen T.E., Karlsbakk E. \& Bergh $\varnothing$. (2008) Occurrence of Francisella piscicida in farmed and wild Atlantic cod, Gadus morhua L., in Norway. Journal of Fish Diseases 31, 525-534.

Ottem K.F., Nylund A., Karlsbakk E., Friis-Møller A.F. \& Kamaishi T. (2009) Elevation of Francisella philomiragia subsp. noatunensis Mikalsen et al. (2007) to Francisella noatunensis comb. nov. [syn. Francisella piscicida Ottem et al. (2008) syn. nov.] and characterization of Francisella noatunensis subsp. orientalis subsp. nov., two important fish pathogens. Journal of Applied Microbiology 106, 1231-1243.

Rosenlund G. \& Halldórsson Ó. (2007) Cod juvenile production: research and commercial developments. Aquaculture 268, 188-194.

Rosenlund G. \& Skretting M. (2006) Worldwide status and perspective on gadoid culture. ICES Journal of Marine Science 63, 194-197.

Samuelsen O.B., Nerland A.H., Jørgensen T., Schrøder M.B., $\mathrm{Sv}^{\circ}$ asand T. \& Bergh Ø. (2006) Viral and bacterial diseases of Atlantic cod Gadus morhua, their prophylaxis and treatment: a review. Diseases of Aquatic Organisms 71, 239254.

Weisburg W.G., Barns S.M., Pelletier D.A. \& Lane D.J. (1991) $16 S$ ribosomal DNA amplification for phylogenetic study. Journal of Bacteriology 173, 697-703.

Zerihun M.A., Feist S.W., Bucke D., Olsen A.B., Tandstad N.M. \& Colquhoun D.J. (2011) Francisella noatunensis subsp. noatunensis is the aetiological agent of visceral granulomatosis in wild Atlantic cod Gadus morhua. Diseases of Aquatic Organisms 95, 6 5-71. 